\title{
Faktor determinan produktivitas kerja pada pekerja wanita
}

\author{
Suci Widiastuti ${ }^{1}$, Fillah Fithra Dieny ${ }^{1}$
}

\begin{abstract}
Background: Participations of women in economy activities is not the new phenomenon in Indonesia. Every years total of female workers increase. However, health or nutrition status of female workers haven't gotten a good attention. This is can effect on lower productivity of female workers than male workers.

Objective :This study was aimed to identify determinant factors of work productivity in female workers.

Method: This study was an analytical study with cross sectional design. The selection of 40 subjects was performed by simple random sampling method. Data on energy intake was obtained from $3 \times 24$ hours food recall form. Body Mass Index (BMI) was measured with anthropometric method. Percentage body fat was measured by Bioelectric Impedance Analyzer (BIA). Haemoglobin was obtained from cyanmethemoglobin method, and data of work productivity was obtained by the comparison of sarong total that weaved succesfully by female workers during 5 work days with company target on time mentioned. The data analyzed with Shapiro wilk, rank spearman, and double linier regression.

Result: Most of subjects (45\%) were deficiency of energy intake. Total of 37,5\% subjects were underweight. More than half of subjects (70\%) were classified as normal percentage body fat. Total of 37,5\% subjects were anemia, and 35\% subjects were not productive. There were correlation between energy intake, percent body fat, BMI and haemoglobin with work productivity $(p=$ $0,016 ; p=0,013 ; p=0,043 ; p=0,000)$. The most correlation variable with work productivity in female workers was haemoglobin (adjusted $R^{2}=0,348$ ).
\end{abstract}

Conclusion: Haemoglobin had the most correlation with work productivity in female workers.

Key words: Determinant factors; energy intake; body mass index; percentage body fat; haemoglobin; work productivity; female workers.

\section{ABSTRAK}

Latar Belakang: Partisipasi wanita dalam kegiatan ekonomi bukan merupakan fenomena yang baru di Indonesia. Jumlah pekerja wanita setiap tahun semakin meningkat. Namun, status kesehatan maupun gizi pekerja wanita umumnya belum mendapat perhatian yang baik. Hal ini dapat mengakibatkan produktivitas tenaga kerja wanita lebih rendah daripada laki-laki. Tujuan : mengidentifikasi faktor determinan produktivitas kerja pada pekerja wanita.

Metode: Penelitian ini merupakan penelitian analitik dengan desain cross sectional. Jumlah sampel sebanyak 40 pekerja wanita diambil dengan metode simple random sampling. Data asupan energi diperoleh melalui kuesioner food recall $3 x 24$ jam. Indeks Massa Tubuh (IMT) diukur menggunakan metode antropometri. Persentase lemak tubuh diukur menggunakan Bioelectric Impedance Analyzer (BIA). Kadar hemoglobin diukur menggunakan metode cyanmethemoglobin, data produktivitas kerja diperoleh melalui perbandingan total sarung yang berhasil ditenun pekerja wanita selama 5 hari kerja dengan target perusahaan sebanyak 6 sarung. Analisis data dengan Shapiro wilk, rank spearman, dan regresi linier ganda.

Hasil: Sebagian besar subjek (45\%) mengalami defisiensi asupan energi. Sebanyak 37,5\% subjek termasuk underweight. Lebih dari separuh subjek (70\%) diklasifikasikan dalam persentase lemak tubuh normal. Sebanyak 37,5\% subjek mengalami anemia, dan 35\% subjek termasuk kategori tidak produktif. Terdapat hubungan antara asupan energi, persentase lemak tubuh, IMT dan kadar hemoglobin dengan produktivitas kerja $(p=0,016 ; p=0,013 ; p=0,043 ; p=0,000)$. Variabel yang paling berhubungan dengan produktivitas kerja pada pekerja wanita adalah kadar hemoglobin ( adjusted $R 2=0,348$ ).

Simpulan: Kadar hemoglobin merupakan variabel yang paling berhubungan dengan produktivitas kerja.

Kata kunci : faktor penentu; asupan energi; indeks massa tubuh; persentase lemak tubuh; hemoglobin; produktivitas kerja; pekerja perempuan

\section{PENDAHULUAN}

Partisipasi wanita dalam kegiatan ekonomi bukan merupakan fenomena yang baru di Indonesia. Banyak wanita, terutama dari golongan bawah sudah berpartisipasi dalam berbagai lapangan pekerjaan. Selain perannya sebagai istri atau ibu dalam keluarga, wanita juga berperan sebagai tenaga kerja untuk

1. Jurusan Gizi Fakultas Kedokteran Universitas Diponegoro pembangunan. ${ }^{1,2}$ Jumlah pekerja wanita di Indonesia setiap tahun semakin meningkat. Pada tahun 2007 mencapai 2,12 juta orang $(35,37 \%){ }^{3}$ Peningkatan ini dilihat dari segi positif bertambahnya tenaga produktif, dan dari segi negatif status kesehatan maupun gizi pekerja umumnya belum mendapat perhatian yang baik. ${ }^{4}$ Terdapat bukti adanya gangguan kesehatan reproduksi yang dialami oleh sebagian pekerja wanita, seperti gangguan haid, gangguan kehamilan, pendarahan, dan keguguran. Hal itu yang dapat menyebabkan penurunan produktivitas kerja yang 
mengakibatkan ongkos produksi menjadi tidak efisien. ${ }^{5}$ Penelitian pada pekerja wanita di Pemalang menunjukkan sebesar 80,9\% pekerja wanita kurang produktif. $^{6}$ Penelitian lain tepatnya di Sukoharjo menunjukkan sebesar $44,1 \%$ pekerja wanitanya kurang produktif. $^{7}$

Produktivitas adalah suatu konsep universal yang menciptakan lebih banyak barang dan jasa bagi kebutuhan manusia, dengan menggunakan sumber daya yang terbatas. ${ }^{8}$ Kesehatan kerja yang optimal dapat dicapai dengan menyesuaikan antara beban kerja, kapasitas kerja, dan beban tambahan akibat lingkungan kerja. ${ }^{1}$ Tercapainya keadaan kesehatan yang optimal, dapat mewujudkan produktivitas kerja yang tinggi. ${ }^{9}$ Produktivitas kerja setiap orang tidak sama, salah satunya tergantung dari tersedianya zat gizi di dalam tubuh. Kekurangan konsumsi zat gizi bagi seseorang dari standar minimum umumnya akan berpengaruh terhadap kondisi kesehatan, aktivitas, dan produktivitas kerja. ${ }^{10,11}$ Penelitian di Jawa Tengah dan Sumatra Barat menunjukkan asupan energi berpengaruh terhadap tingkat produktivitas pekerja. ${ }^{12}$

Status gizi merupakan salah satu faktor penting yang mempengaruhi produktivitas kerja. Ketahanan dan kemampuan tubuh untuk melakukan pekerjaan dengan produktivitas yang memadai akan lebih dimiliki oleh individu dengan status gizi baik. Status gizi dapat digambarkan melalui indeks massa tubuh (IMT), persentase lemak tubuh, dan kadar hemoglobin. ${ }^{13,14}$ Beberapa penelitian menunjukkan adanya hubungan antara IMT dengan produktivitas kerja. ${ }^{9}{ }^{15}$ Seorang tenaga kerja dengan keadaan gizi yang baik akan memiliki kapasitas kerja dan ketahanan tubuh yang lebih baik. Rendahnya efisiensi kerja akibat keadaan gizi yang kurang dapat menurunkan produktivitas kerja. ${ }^{7}$ Beberapa penelitian menunjukkan bahwa ada hubungan antara persentase lemak tubuh dengan produktivitas kerja. Pekerja yang memiliki persentase lemak tubuh kurang maka akan mempengaruhi kapasitas kerja fisiknya. Selain itu persentase lemak tubuh merupakan faktor yang mempengaruhi tingkat kesegaran jasmani. Setiap tenaga kerja dituntut memiliki kesegaran jasmani yang baik sehingga tidak merasa cepat lelah dan performansi kerja tetap stabil untuk waktu yang cukup lama. Tingkat kesegaran jasmani yang rendah akan mempertinggi risiko kelelahan otot yang dapat menyebabkan keterbatasan dalam menerima beban kerja. ${ }^{7,13,16}$

Produktivitas kerja pada wanita juga dapat dipengaruhi oleh status anemia. ${ }^{17}$ Survei nasional tahun 2001 menunjukkan prevalensi anemia pada Wanita Usia Subur (WUS) kawin dan tidak kawin masingmasing sebesar $26,9 \%$ dan $24,5 \% .{ }^{18}$ Pekerja wanita merupakan salah satu kelompok rentan anemia gizi. Hal ini disebabkan oleh kurangnya zat besi dalam makanan dan pekerjaan yang berat, serta secara alamiah wanita setiap bulan mengalami menstruasi. Salah satu tanda seseorang mengalami anemia dapat dilihat dari pemeriksaan kadar hemoglobin yang menunjukkan angka kurang dari normal. ${ }^{19,20}$ Penelitian pada pekerja wanita di Sumatera Utara menunjukkan ada hubungan positif antara kadar hemoglobin dengan produktivitas kerja. ${ }^{21}$

Berdasarkan latar belakang di atas, maka perlu diteliti faktor determinan produktivitas kerja pada pekerja wanita penenun sarung di Kabupaten Tegal. Hal itu dikarenakan Berdasarkan data Riset Kesehatan Dasar (Riskesdas) tahun 2007, prevalensi kurang energi kronis (KEK) pada wanita usia subur (WUS) di kabupaten/kota povinsi Jawa Tengah tertinggi berada di kabupaten Tegal $(27,6 \%)$, selain itu masih banyak pekerja wanita di daerah tersebut yang bekerja sebagai buruh untuk menopang ekonomi keluarganya, padahal sebagian besar buruh wanita tingkat pendidikannya masih rendah dan kebanyakan merupakan penduduk dengan sosial ekonomi menengah ke bawah.

\section{BAHAN DAN METODE}

Penelitian ini merupakan penelitian analitik observasional dengan rancangan cross-sectional . penelitian dilakukan di PT Asaputex Jaya Kecamatan Talang Kabupaten Tegal. Subjek dalam penelitian ini sebanyak 40 subjek di bagian penenunan sarung dengan menggunakan metode pengambilan sampel yaitu simple random sampling, yang sebelumnya telah dipilih sesuai dengan kriteria inklusi yakni wanita usia 20-40 tahun, massa kerja minimal 1 tahun, tidak dalam keadaan berpuasa, sakit, haid, hamil, menyusui, masa nifas, dan menopause, serta tidak menggunakan obat tertentu yang dapat menaikkan kadar hemoglobin darah. Pekerja di bagian penenunan sarung mempunyai beban kerja yang sama yaitu bekerja dalam posisi duduk, lamanya waktu kerja dan tugas yang sama.

Data yang dikumpulkan dalam penelitian adalah karakteristik subjek (umur, pendidikan, pendapatan per kapita, dan pengetahuan gizi), asupan energi, indeks massa tubuh (IMT), persentase lemak tubuh, kadar hemoglobin dan produktivitas kerja. Variabel dalam penelitian ini meliputi variabel bebas antara lain asupan energi, IMT, persentase lemak tubuh dan kadar hemoglobin, sedangkan variabel terikat adalah produktivitas kerja.

Data karakteristik subjek yang berupa pendapatan per kapita diperoleh dari pendapatan keluarga dibagi dengan jumlah anggota keluarga (besar keluarga). Sementara itu pendapatan keluarga merupakan penjumlahan dari seluruh pendapatan yang diperoleh seluruh anggota keluarga. Pendapatan kurang dari 1 dollar AS atau sekitar Rp 8.000,00/kapita/hari atau Rp 240.000,00/kapita/bulan termasuk dalam 
kategori miskin. ${ }^{22}$ Kategori tingkat pendapatan per kapita per bulan dikategorikan menjadi dua, yaitu miskin ( < Rp 240.000,00) dan tidak miskin ( $\geq \mathrm{Rp}$ 240.000,00).

Pengetahuan gizi pekerja wanita diketahui melalui skor kemampuan dalam menjawab kuesioner dengan 20 pertanyaan yang berisi tentang gizi seimbang, jenis dan fungsi zat gizi bagi tubuh. Skor penilaian untuk jawaban benar $=1$ dan salah $=0$. Pengetahuan gizi yang baik jika $>80 \%$ jawaban benar, cukup (60-80\% jawaban benar) dan kurang $(<60 \%$ jawaban benar). ${ }^{23}$

Asupan energi adalah jumlah rerata makanan dan minuman yang dikonsumsi selama tiga hari dalam waktu yang tidak berurutan (dua hari kerja dan satu hari libur kerja). Asupan energi diukur dengan metode food recall 3 x 24 jam. Pengambilan data dilakukan dengan wawancara terhadap responden. Data yang diperoleh (ukuran rumah tangga) dikonversikan ke dalam satuan gram kemudian dihitung nilai energinya menggunakan NutriSurvey. Hasil analisis rata-rata asupan energi kemudian dibandingkan dengan Angka Kecukupan Gizi (AKG) individu kemudian dikalikan $100 \%$ maka didapatkan persen tingkat konsumsi energi. Tingkat konsumsi energi termasuk kategori kurang bila $<80 \%$, baik (80-100\%), dan lebih (>100\%). ${ }^{24}$

Indeks Massa Tubuh (IMT) didefinisikan sebagai hasil pengukuran antropometri berdasarkan berat badan dan tinggi badan untuk menentukan status gizi. Diperoleh melalui pengukuran berat badan menggunakan timbangan digital dengan ketelitian 0,1 $\mathrm{kg}$, serta pengukuran tinggi badan menggunakan microtoise kapasitas $200 \mathrm{~cm}$ dengan ketelitian $0,1 \mathrm{~cm}$. Status gizi menurut ambang batas IMT untuk orang Asia yaitu underweight $\left(<18,5 \mathrm{~kg} / \mathrm{m}^{2}\right)$, normal $(18,5-$ $\left.22,9 \mathrm{~kg} / \mathrm{m}^{2}\right)$, overweight $\left(23-24,9 \mathrm{~kg} / \mathrm{m}^{2}\right)$, obesitas tingkat I $\left(25-29,9 \mathrm{~kg} / \mathrm{m}^{2}\right)$, dan obesitas tingkat II $(\geq 30$ $\left.\mathrm{kg} / \mathrm{m}^{2}\right){ }^{25} \quad$ Sedangkan Persentase lemak tubuh didefinisikan sebagai persen massa lemak tubuh dibandingkan berat badan total yang diperoleh melalui alat Bioelectrical Impedance Analyzer (BIA) dalam satuan persen (\%). Data persentase lemak tubuh dapat diketahui subjek yang tergolong underfat jika persentase lemak tubuhnya <16\%, normal (16-31\%), overfat (32-35\%), dan obesitas (>35\%). ${ }^{26}$

Kadar Hemoglobin merupakan kadar senyawa pembawa oksigen pada sel darah merah dalam tubuh pekerja wanita, diukur menggunakan metode cyanmethemoglobin oleh petugas laboratorium. Data kadar hemoglobin kemudian dikategorikan menjadi dua yaitu anemia $(<12 \mathrm{~g} / \mathrm{dl})$ dan normal $(\geq 12 \mathrm{~g} / \mathrm{dl}){ }^{27}$

Produktivitas kerja sebagai variabel terikat dalam penelitian ini adalah total sarung yang berhasil ditenun pekerja wanita selama 5 hari kerja dibandingkan dengan target perusahaan pada waktu tersebut (6 sarung). Data produktivitas kerja kemudian dikategorikan menjadi dua yaitu produktif $(\geq 6$ sarung $/ 5$ hari kerja/orang) dan tidak produktif ( $<6$ sarung/5 hari kerja/orang).

Analisis univariat dilakukan untuk mendeskripsikan setiap variabel penelitian meliputi nilai minimum dan maksimum, nilai rata-rata, standar deviasi dan deskripsi dari beberapa data meliputi ; usia subjek, pendidikan, pendapatan keluarga, pengetahuan gizi, asupan energi, IMT, persentase lemak tubuh, kadar hemoglobin dan produktivitas kerja. Sebelum uji hipotesis, dilakukan uji kenormalan dengan Shaphiro wilk yang kemudian dilanjutkan dengan analisis bivariat yaitu menghubungkan masing-masing variabel yaitu asupan energi, IMT , persentase lemak tubuh dan kadar hemoglobin dengan produktivitas kerja menggunakan uji korelasi Rank spearman. Kemudian data asupan energi, IMT, persentase lemak tubuh, dan kadar hemoglobin dilanjutkan ke uji multivariat menggunakan uji regresi linier ganda. ${ }^{28}$

\section{HASIL}

PT Asaputex Jaya merupakan perusahaan yang bergerak di bidang penenunan sarung yang terletak di Kabupaten Tegal. Pekerja dalam perusahaan ini lebih didominasi wanita yang berusia antara 15-55 tahun. Proses penenunan sarung masih menggunakan alat manual yaitu ATBM (Alat Tenun Bukan Mesin), sedangkan lama kerja 10 jam/hari dalam 5 hari kerja.

Pada bagian penenunan sarung, posisi pekerja saat menenun sarung yaitu duduk. Disamping itu, terdapat kegaduhan dan kebisingan yang ditimbulkan dari suara alat tenun sehingga dapat mengganggu konsentrasi, mengganggu daya ingat, dan menyebabkan kelelahan psikologis. Belum ada upaya penanganan untuk mengurangi/meredam efek dari suara tersebut. Perusahaan ini tidak menyediakan makanan atau minuman tambahan bagi pekerjanya. Selain itu, perusahaan ini juga belum mempunyai kantin khusus. Para buruh memperoleh makanan dengan cara membeli di warung dan ada juga yang makan di rumah.

Hasil penelitian diperoleh 40 subjek dengan rentang usia berkisar antara 20-40 tahun. Usia subjek pada penelitian ini sebagian besar termasuk dalam kategori wanita usia subur (WUS), dengan frekuensi terbanyak yaitu pada usia $20-25$ tahun $(37,5 \%)$. 
Tabel 1. Distribusi subjek menurut usia, tingkat pendidikan, pendapatan dan pengetahuan

\begin{tabular}{lll}
\hline Kategori & $\mathbf{n = 4 0}$ & $\mathbf{\%}$ \\
\hline Usia & & \\
$20-25$ & 15 & 37,5 \\
$26-30$ & 11 & 27,5 \\
$31-35$ & 9 & 22,5 \\
$36-40$ & 5 & 12,5 \\
Tingkat pendidikan & & \\
Tidak pernah sekolah & 1 & 2,5 \\
SD/MI & 26 & 65,0 \\
SMP/MTs & 12 & 30,0 \\
SMU/MA & 1 & 2,5 \\
Tingkat pendapatan & & \\
Miskin & 14 & 35,0 \\
Tidak miskin & 26 & 65,0 \\
Tingkat pengetahuan & & \\
Cukup & 18 & 45,0 \\
Baik & 22 & 55,0 \\
\hline
\end{tabular}

Tabel 2. Nilai minimum, maksimum, rerata dan standar deviasi variabel penelitian

\begin{tabular}{lllll}
\hline Variabel & n & Min & Maks & Rerata \pm SD \\
\hline Asupan energi (kkal) & 40 & 797 & 3993 & $1802 \pm 757$ \\
IMT $\left(\mathrm{kg} / \mathrm{m}^{2}\right)$ & 40 & 14,73 & 30,20 & $20,45 \pm 3,62$ \\
Persentase lemak tubuh (\%) & 40 & 10,20 & 37,60 & $21,7 \pm 6,4$ \\
Kadar hemoglobin (gr/dl) & 40 & 9 & 13,6 & $11,95 \pm 1,02$ \\
Produktivitas kerja (satuan) & 40 & 4 & 11 & $6,43 \pm 1,6$ \\
\hline
\end{tabular}

Hasil perhitungan diperoleh rerata asupan energi pada subjek yaitu $1802 \pm 757$ kkal. Sebanyak 18 subjek (45\%) mempunyai tingkat konsumsi energi yang kurang, namun ditemukan juga 9 subjek $(22,5 \%)$ yang tergolong tingkat asupan energinya berlebih, salah satunya mencapai $3993 \mathrm{kkal}$.

Tabel 3. Distribusi subjek menurut tingkat konsumsi energy

\begin{tabular}{|c|c|c|}
\hline Kategori tingkat konsumsi energi & $\mathbf{n}$ & $\%$ \\
\hline Kurang & 18 & 45 \\
\hline Baik & 13 & 32,5 \\
\hline Lebih & 9 & 22,5 \\
\hline Total & 40 & 100 \\
\hline
\end{tabular}

Sedangkan hasil pengukuran IMT diperoleh rerata IMT pada subjek yaitu $20,45+3.62 \mathrm{~kg} / \mathrm{m} 2$. Setelah disesuaikan dengan rekomendasi untuk orang Asia sebagian besar ditemukan subjek yang mempunyai status gizi underweight dan normal dengan proporsi yang sama yaitu masing-masing sebanyak $37,5 \%$. Sedangkan sedangkan subjek yang mengalami masalah gizi lebih yaitu overweight maupun obesitas juga ditemukan meskipun prevalensinya lebih rendah yaitu masing masing $15 \%$ dan $10 \%$.

Tabel 4. Distribusi subjek menurut IMT

\begin{tabular}{lcc}
\hline Kategori IMT & n & \% \\
\hline Underweight & 15 & 37,5 \\
Normal & 15 & 37,5 \\
Overweight & 6 & 15,0 \\
Obese level I & 3 & 7,5 \\
Obese level II & 1 & 2,5 \\
\hline Total & 40 & 100 \\
\hline
\end{tabular}


Persentase lemak tubuh menunjukkan rerata yaitu $21,7 \pm 6,4 \%$, setelah disesuaikan dengan klasifikasi persentase lemak tubuh pada wanita menunjukkan lebih dari separuh subjek yaitu $70 \%$ termasuk dalam kategori persentase lemak tubuh normal, namun masih ditemukan subjek dengan persen lemak tubuh underfat (20\%).

Tabel 5. Distribusi subjek menurut persentase lemak tubuh

\begin{tabular}{lll}
\hline Kategori persentase lemak tubuh & $\mathbf{n}$ & $\mathbf{\%}$ \\
\hline Underfat & 8 & 20,0 \\
Normal & 28 & 70,0 \\
Overfat & 3 & 7,5 \\
Obese & 1 & 2,5 \\
\hline Total & 40 & 100 \\
\hline
\end{tabular}

Hasil pengukuran kadar $\mathrm{Hb}$ menunjukkan rerata $\mathrm{Hb}$ sebesar $11,95 \pm 1,02 \mathrm{gr} / \mathrm{dl}$. Terdapat subjek yang memiliki kadar $\mathrm{Hb}$ sangat rendah yaitu $9 \mathrm{gr} / \mathrm{dl}$.
Berdasarkan ambang batas normal kadar $\mathrm{Hb}$ pada wanita ditemukan sebanyak 15 orang $(37,5 \%)$ subjek yang mengalami anemia.

Tabel 6. Distribusi subjek menurut kadar hemoglobin

\begin{tabular}{lll}
\hline Kategori kadar Hb & $\mathbf{n}$ & $\mathbf{\%}$ \\
\hline Anemia & 15 & 37,5 \\
Normal & 25 & 62,5 \\
\hline Total & 40 & 100 \\
\hline
\end{tabular}

Data produktivitas kerja, rata-rata pekerja dapat menghasilkan 6 buah sarung kerja, sedangkan bila dibandingkan dengan target perusahaan yang sudah ditetapkan, sebanyak $35 \%$ subjek termasuk dalam kategori tenaga kerja yang tidak produktif. Kapasitas produksi terendah yaitu 4 buah sarung dan tertinggi 11 buah sarung.

Tabel 7. Distribusi subjek menurut produktivitas kerja

\begin{tabular}{lll}
\hline Kategori produktivitas kerja & $\mathbf{n}$ & $\mathbf{\%}$ \\
\hline Tidak produktif & 14 & 35 \\
Produktif & 26 & 65 \\
\hline Total & 40 & 100 \\
\hline
\end{tabular}

Analisis bivariat digunakan untuk melihat hubungan antara masing-masing variabel yaitu asupan energi, IMT, persentase lemak tubuh, dan kadar hemoglobin dengan produktivitas kerja. Hasilnya asupan energi dengan produktivitas kerja menunjukkan ada hubungan yang bermakna $(\mathrm{r}=0,378 ; p=0,016)$.

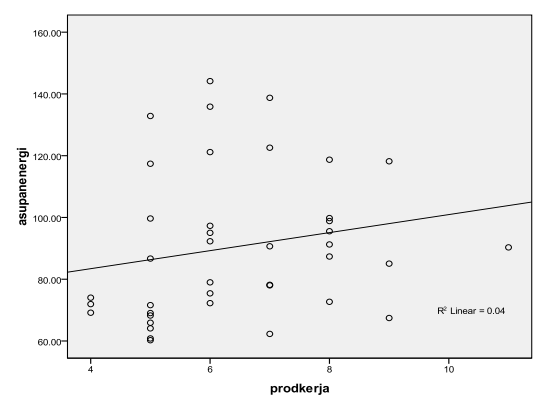

Gambar 1. Hubungan antara asupan energi dengan produktivitas kerja
Begitu juga dengan IMT dan persentase lemak tubuh dengan produktivitas kerja terdapat hubungan bermakna ( $\mathrm{r}=0,391 ; p=0,013, \mathrm{r}=0,321 ; p=0,043)$. Sedangkan kadar hemoglobin dengan produktivitas kerja juga terdapat korelasi positif $(\mathrm{r}=0,736 ; p=0,000)$.

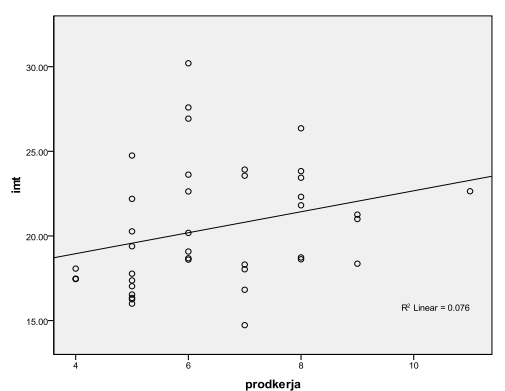

Gambar 2. Hubungan antara IMT dengan produktivitas kerja 


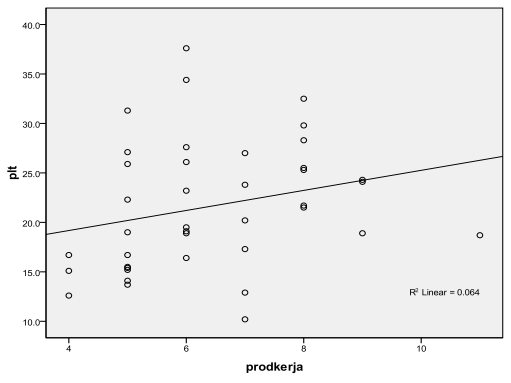

Gambar 3. Hubungan antara persentase lemak tubuh dengan produktivitas kerja

Hasil analisis multivariat menggunakan regresi linier ganda diperoleh kadar hemoglobin merupakan faktor yang paling berhubungan dengan produktivitas kerja $(p=0,000)$. Nilai Adjusted $R^{2}=0,348(34,8 \%)$, hal tersebut dapat diartikan bahwa $34,8 \%$ produktivitas kerja dapat dipengaruhi oleh asupan energi, IMT, persentase lemak tubuh dan kadar $\mathrm{Hb}$, sedangkan $65,2 \%$ dipengaruhi oleh variabel lain. Persamaan regresi yang diperoleh, produktivitas kerja $=-5,640+$ 0,906 kadar $\mathrm{Hb}$, artinya setiap kenaikan kadar $\mathrm{Hb}$ sebesar $1 \mathrm{~g} / \mathrm{dl}$ akan meningkatkan produktivitas kerja pekerja wanita sebesar 0,906 satuan.

\section{PEMBAHASAN}

Karakteristik subjek dalam penelitian ini meliputi usia, tingkat pendidikan, pendapatan keluarga, dan pengetahuan gizi. Berdasarkan hasil penelitian diketahui bahwa usia subjek berkisar antara 20-40 tahun, dengan frekuensi terbesar yaitu usia 2025 tahun sebanyak 15 subjek (37,5\%), selanjutnya 2630 tahun sebanyak 11 subjek (27,5\%), 31-35 tahun sebanyak 9 subjek (22,5\%), dan 36-40 tahun sebanyak 5 subjek (12,5\%). Usia antara 20-40 tahun ini termasuk dalam kategori wanita usia subur. ${ }^{29}$ Wanita lebih banyak mengalami gangguan kesehatan reproduksi dibanding kaum pria, karena ciri biologis yang melekat pada wanita. Gangguan kesehatan reproduksi yang diderita wanita lebih beragam, sejak menstruasi, hubungan seksual, sampai terjadinya kehamilan dan kelahiran dengan risiko kesehatan yang menyertainya. ${ }^{5,30}$ Selain itu, kebanyakan kinerja fisik mencapai puncak dalam umur pertengahan 20 tahun, kemudian menurun dengan bertambahnya umur dan akan berkurang sebanyak 20\% di usia 60 tahun. Berkurangnya kebutuhan tenaga tersebut dikarenakan telah menurunnya kekuatan fisik. ${ }^{31}$

Sebagian besar subjek dalam penelitian ini masih mempunyai tingkat pendidikan yang rendah karena belum memenuhi wajib belajar 9 tahun yaitu sebanyak 26 subjek (65\%) berpendidikan SD/MI, bahkan terdapat subjek yang tidak pernah sekolah yaitu sebanyak 1 subjek $(2,5 \%)$. Sedangkan subjek yang memenuhi wajib belajar 9 tahun yaitu subjek

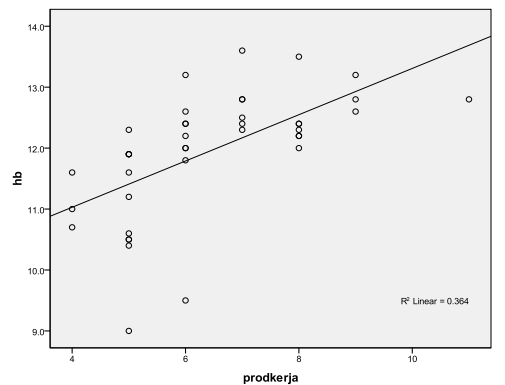

Gambar 4. Hubungan antara kadar $\mathrm{Hb}$ dengan produktivitas kerja

dengan pendidikan SMP/MTs sebanyak 12 subjek (30\%) dan hanya 1 subjek (2,5\%) yang berhasil menempuh tingkat pendidikan sampai ke jenjang SMU/MA.

Berdasarkan hasil penelitian diketahui $65 \%$ subjek mempunyai pendapatan $\geq \mathrm{Rp}$ 240.000,00/kapita/bulan. Sebagian subjek lebih mementingkan kebutuhan pangan dibandingkan kebutuhan non pangan. Namun, pemenuhan pangan subjek lebih mengutamakan dari segi kuantitasnya daripada kualitas pangan yang dikonsumsi. Pendapatan keluarga merupakan salah satu faktor yang menentukan kualitas dan kuantitas makanan yang dikonsumsi seluruh anggota keluarga, sehingga akan berpengaruh terhadap kondisi kesehatan dan gizi keluarga. ${ }^{33}$

Dilihat dari tingkat pengetahuan gizi subjek menunjukkan sebagian besar terdapat pada kategori baik yaitu 22 subjek (55\%) dan 18 subjek (45\%) dengan kategori cukup. Hasil analisis bivariat antara pengetahuan gizi dengan asupan energi menunjukkan bahwa tidak adanya hubungan. Hal ini didukung oleh hasil penelitian di Bangladesh yang menyatakan bahwa pengetahuan gizi yang diperoleh pekerja wanita dianggap belum mampu untuk mengubah persepsi pekerja wanita terhadap gizi dan kesehatan tanpa adanya komunikasi dan interaksi secara langsung dengan petugas kesehatan terkait ${ }^{34}$

Hasil penelitian menunjukkan subjek mempunyai tingkat pendidikan yang rendah, tetapi tingkat pengetahuan gizi termasuk dalam kategori baik. Berdasarkan hasil wawancara diketahui bahwa pengetahuan gizi pekerja wanita dapat dipengaruhi oleh beberapa faktor, antara lain yaitu lingkungan sosial, pelayanan kesehatan, dan media massa.. Pekerja wanita dengan pengetahuan gizi yang baik lebih memahami keterkaitan antara konsumsi makanan dengan kesehatan dirinya, sehingga pekerja wanita berusaha untuk mengkonsumsi makanan yang sehat. Sedangkan pengetahuan yang kurang menyebabkan bahan makanan bergizi yang tersedia tidak dikonsumsi secara optimal. ${ }^{23,34,35}$

Hasil penelitian ini menunjukkan bahwa sebagian subjek yaitu 26 subjek (65\%) termasuk 
dalam kategori produktif. Namun, masih terdapat sebanyak 14 subjek (35\%) yang termasuk dalam kategori tidak produktif. Hal ini sama dengan hasil penelitian yang dilakukan pada pekerja wanita di Semarang yang menunjukkan bahwa sebesar 33,3\% pekerja wanitanya tidak produktif. ${ }^{9}$

Hasil penelitian ini menunjukkan sebagian besar subjek ditemukan asupan energinya masih kurang yaitu 18 subjek (45\%), 13 subjek $(32,5 \%)$ termasuk kategori asupan energi baik, dan terdapat 9 subjek $(22,5 \%)$ termasuk dalam kategori lebih. Hasil analisis bivariat menunjukkan terdapat hubungan yang bermakna antara asupan energi dengan produktivitas kerja. Berbagai penelitian baik yang dilakukan di luar negeri maupun di Indonesia menunjukkan bahwa keadaan defisiensi energi dapat menghambat aktivitas kerja yang akan menurunkan produktivitas kerja. ${ }^{13} \mathrm{Hal}$ ini disebabkan karena kemampuan kerja seseorang sangat dipengaruhi oleh jumlah energi yang tersedia, dimana energi tersebut diperoleh dari makanan seharihari dan bilamana jumlah makanan sehari-hari tidak memenuhi kebutuhan tubuh, maka energi didapat dari cadangan tubuh. Tubuh akan mampu menerima beban kerja dengan baik bila energi yang disediakan terpenuhi. Energi tersebut didapatkan dari pembakaran cadangan zat gizi yaitu karbohidrat, lemak dan protein. ${ }^{37}$ Penelitian lain didapatkan $15 \%$ tenaga kerja wanita kekurangan energi dan protein menyebabkan tenaga kerja menjadi lambat berpikir dan bertindak, serta cepat lelah. ${ }^{38}$

Hasil penelitian ini menunjukkan sebanyak 15 subjek $(37,5 \%)$ termasuk underweight, 15 subjek $(37,5 \%)$ termasuk normal. Namun, terdapat subjek yang mengalami kegemukan yaitu sebanyak 6 subjek $(15 \%)$ termasuk overweight, 3 subjek $(7,5 \%)$ termasuk obesitas tingkat I, dan 1 subjek $(2,5 \%)$ termasuk obesitas tingkat II. Rendahnya IMT subjek dapat disebabkan oleh faktor lingkungan kerja. Selain itu, beban kerja yang berlebihan berisiko menyebabkan penurunan berat badan. Sedangkan subjek penelitian yang memiliki kelebihan berat badan dapat disebabkan karena faktor sosial ekonomi, motivasi kerja, dsb. ${ }^{8}$

Kesehatan tenaga kerja dan produktivitas kerja erat kaitannya dengan keadaan atau status gizi. Seorang tenaga kerja dengan keadaan gizi yang baik akan memiliki kapasitas kerja dan ketahanan tubuh yang lebih baik. Tenaga kerja dengan status gizi di bawah normal, meskipun persentasenya tidak besar, tetapi perlu mendapat perhatian. Hal ini karena konsumsi energi yang kurang memadai akan menyebabkan kebutuhan energi untuk bekerja akan diambil dari energi cadangan yang terdapat dalam sel. Apabila hal ini terjadi, dapat mengakibatkan tenaga kerja yang bersangkutan tidak dapat melakukan pekerjaan secara baik dan produktivitas kerjanya akan menurun bahkan dapat mencapai target rendah. ${ }^{8,39}$ Sebaliknya, tenaga kerja dengan status gizi lebih atau obesitas maka orang tersebut kurang gesit dan lamban dalam bekerja. Sedangkan orang yang mempunyai berat badan normal akan lebih lincah dalam bekerja. Seseorang yang kurus (kekurangan berat badan), maka akan kurang mampu bekerja keras. ${ }^{1}$

Hasil analisis bivariat menunjukkan bahwa terdapat hubungan yang bermakna antara IMT dengan produktivitas kerja, artinya seorang pekerja dengan IMT yang rendah maka produktivitas kerja subjek cenderung semakin menurun. Terdapatnya hubungan antara IMT dengan produktivitas kerja dimungkinkan karena IMT dapat digunakan untuk menentukan status gizi seseorang, dan produktivitas kerja adalah kesanggupan tubuh dalam menerima beban kerja. Kekurangan energi akan menyebabkan tubuh lemah dan tidak mampu melakukan aktivitas dengan baik. ${ }^{40}$ Hal tersebut akan mengakibatkan penurunan tingkat produktivitas kerja seseorang, untuk itu pemenuhan asupan gizi yang baik untuk memperoleh status gizi yang baik pula sangat perlu diperhatikan. ${ }^{8}$

Hasil penelitian ini menunjukkan bahwa lebih dari separuh subjek yaitu 28 subjek $(67,5 \%)$ termasuk dalam kategori persen lemak tubuh normal, 8 subjek $(22,5 \%)$ termasuk dalam kategori underfat, 3 subjek $(7,5 \%)$ termasuk dalam kategori overfat, dan 1 subjek $(2,5 \%)$ termasuk dalam kategori obesitas. Hasil analisis bivariat menunjukkan bahwa terdapat hubungan yang bermakna antara persentase lemak tubuh dengan produktivitas kerja. Seorang pekerja wanita dengan persentase lemak tubuh yang tidak optimal maka akan berpengaruh pada penurunan produktivitas kerjanya. Persentase lemak tubuh yang berlebihan ataupun kekurangan akan mengakibatkan produktivitas kerja yang tidak optimal.

Komposisi tubuh seseorang meliputi dua komponen yaitu massa lemak atau persentase lemak tubuh dan massa bebas lemak. Persentase lemak tubuh adalah perbandingan antara lemak tubuh dengan massa tubuh tanpa lemak. Simpanan utama energi tubuh adalah lemak yang berupa trigliserida pada jaringan adiposa. Jumlah simpanan lemak bervariasi berdasarkan perubahan kebutuhan untuk pertumbuhan, reproduksi dan penuaan sesuai fluktuasi pada faktor lingkungan dan fisiologis seperti asupan zat gizi (karbohidrat, lemak, dan protein) dan aktifitas fisik. ${ }^{27,40}$ Jaringan lemak tubuh merupakan jaringan yang tidak aktif dalam proses metabolisme dan fungsi utamanya sebagai cadangan energi. Apabila energi yang dihasilkan oleh bahan makanan tidak mencukupi untuk keperluan tubuh, maka sebagian dari simpanan lemak akan diubah kembali ke dalam energi. ${ }^{26}$

Pada orang yang kekurangan simpanan lemak tubuh dalam jangka waktu yang lama akan menyebabkan penurunan produktivitas kerja karena dalam menerima kapasitas kerja tidak optimal. 
Kapasitas kerja merupakan kemampuan untuk menyelesaikan pekerjaannya pada waktu tertentu. Kapasitas kerja yang baik seperti status kesehatan dan gizi kerja yang baik serta kemampuan fisik yang prima diperlukan agar seorang pekerja dapat melakukan pekerjaannya dengan baik sehingga produktivitas kerja juga meningkat., ${ }^{2,83}$ Sebaliknya, kelebihan lemak yang tersimpan dalam jaringan adiposa menyebabkan seseorang menjadi kelebihan berat badan dan selanjutnya dapat terjadi obesitas, yang berdampak pada penampilan menjadi kurang aktif karena sulit untuk bergerak. ${ }^{41}$ Lemak tubuh yang berlebih juga dikaitkan dengan penurunan tingkat kesegaran jasmani yang diukur dengan $\mathrm{VO}_{2}$ max. ${ }^{42}$ Wanita mempunyai $\mathrm{VO}_{2}$ max $15-30 \%$ lebih rendah dari laki-laki dalam hal pekerjaan fisik. Kondisi tersebut menyebabkan persentase lemak tubuh wanita lebih tinggi daripada laki-laki. ${ }^{8,42}$

Hasil penelitian menunjukkan 25 subjek $(62,5 \%)$ termasuk kategori kadar hemoglobin normal dan 15 subjek $(37,5 \%)$ termasuk anemia. Rendahnya kadar hemoglobin dapat disebabkan karena defisiensi asupan zat gizi seperti zat besi, asam folat, dan vitamin B12. Secara umum penyebab anemia defisiensi zat besi yaitu asupan zat besi tidak cukup dan penyerapan tidak adekuat, serta peningkatan kebutuhan zat besi untuk pembentukan sel darah merah yaitu pada masa menstruasi, kehamilan, dan menyusui. ${ }^{43}$ Hasil analisis bivariat terdapat hubungan yang bermakna antara kadar $\mathrm{Hb}$ dengan produktivitas kerja, artinya pekerja wanita yang mempunyai kadar $\mathrm{Hb}$ yang rendah maka dapat menurunkan produktivitas kerjanya. Penelitian lain di Sukoharjo menunjukkan hasil yang sama yaitu terdapat hubungan yang bermakna antara kadar $\mathrm{Hb}$ dengan produktivitas kerja. ${ }^{6,7}$

Anemia pada pekerja wanita ini dapat menurunkan produktivitas kerja mereka karena berbagai penelitian telah membuktikan bahwa pada pekerja yang anemia, mempunyai produktivitas kerja yang lebih rendah dibandingkan pekerja yang tidak anemia. ${ }^{17}$ Hasil penelitian pada buruh yang bekerja di berbagai bidang ekonomi menunjukkan bahwa buruh dengan anemia mempunyai produktivitas kerja yang menurun secara nyata dengan perkiraan penurunan sebesar $20 \% .^{8}$

Hasil analisis multivariat diperoleh bahwa kadar $\mathrm{Hb}$ merupakan faktor yang paling berhubungan dengan produktivitas kerja. Hasil analisis regresi linier ganda didapatkan nilai nilai $p=0,000$ yang berarti bahwa asumsi linier terpenuhi dan Adjusted $R^{2}=0,348$ $(34,8 \%)$. Hal tersebut dapat diartikan bahwa $34,8 \%$ produktivitas kerja dapat dipengaruhi oleh asupan energi, IMT, persentase lemak tubuh dan kadar $\mathrm{Hb}$, sedangkan 65,2\% dipengaruhi oleh variabel lain. Persamaan regresi yang diperoleh, produktivitas kerja $=-5,640+0,906$ kadar $\mathrm{Hb}$, artinya setiap kenaikan kadar $\mathrm{Hb}$ sebesar 1 g/dl akan meningkatkan produktivitas kerja pekerja wanita sebesar 0,906 satuan.

Kadar $\mathrm{Hb}$ ini dapat digunakan untuk menentukan status gizi seseorang dan juga digunakan sebagai parameter untuk menunjukkan keadaan anemia zat besi. ${ }^{43}$ Wanita mempunyai risiko tinggi untuk menderita anemia zat besi, karena terjadi peningkatan kebutuhan terhadap zat besi akibat adanya menstruasi. ${ }^{31}$ Anemia zat besi akan menyebabkan rendahnya tingkat produktivitas kerja ${ }^{8}$

Fungsi utama hemoglobin dalam tubuh bergantung pada kemampuannya untuk bergabung dengan oksigen dalam paru dan kemudian melepaskan oksigen ini dalam kapiler jaringan di mana tekanan gas oksigen jauh lebih rendah daripada di paru-paru. Saat melakukan aktifitas berat, kebutuhan energi akan sangat meningkat yang berarti kebutuhan oksigen oleh jaringan juga sangat meningkat, untuk mengatasi hal tersebut jantung harus bekerja ekstra berat dengan meningkatkan volume dan frekuensi denyut jantung untuk memasok oksigen ke jaringan otot yang melakukan aktifitas. Selama bekerja ini, tubuh seseorang membutuhkan 20 kali jumlah oksigen normal dan sel-sel otot memakai oksigen dengan sangat cepat. ${ }^{43}$ Oksigen dalam pembuluh darah ini diangkut oleh hemoglobin. Kurangnya asupan zat besi dapat menyebabkan produksi sel darah merah akan menurun jumlah dan besarnya, sehingga produksi hemoglobin juga ikut menurun. Rendahnya hemoglobin dalam darah akan mempengaruhi banyaknya oksigen yang dapat diangkut ke otot-otot yang sangat membutuhkan oksigen tersebut untuk perubahan energi ketika bekerja keras. ${ }^{44}$ Oksigen dibutuhkan pada proses pembakaran zat-zat gizi (karbohidrat, lemak, protein) untuk menghasilkan energi. ${ }^{40}$

Menurunnya produktivitas kerja pada seseorang yang anemia dapat disebabkan gangguan dalam metabolisme energi, serta menurunnya hemoglobin darah. Akibatnya, metabolisme energi di dalam otot terganggu dan terjadi penumpukan asam laktat yang menyebabkan rasa lelah. ${ }^{43} \mathrm{Hal}$ ini sebagai akibat terjadinya hipoksia yang lebih awal pada wanita yang mengalami anemia sehingga akan mengganggu produktivitas kerja, karena rasa lelah, letih lesu membuat seseorang malas untuk bekerja. ${ }^{45}$ Sedangkan kadar hemoglobin yang cukup akan meningkatkan kemampuan sistem peredaran darah dan pernafasan untuk mendistribusikan oksigen ke otot-otot yang bekerja sesuai dengan kebutuhan untuk memulihkan tubuh dari efek bekerja. ${ }^{17}$ 


\section{SIMPULAN}

Berdasarkan hasil penelitian terdapat hubungan antara asupan energi, IMT, persentase lemak tubuh dan kadar hemoglobin dengan produktivitas kerja. Sedangkan, analisis multivariat menunjukkan kadar $\mathrm{Hb}$ merupakan variabel yang paling berhubungan dengan produktivitas kerja.

\section{DAFTAR PUSTAKA}

1. Suma'mur. Ergonomi untuk produktivitas. Jakarta: CV Haji Masagung; 2001.hal. 84, 197.

2. Loscocco KA, Spitze G. Working conditions, social support, and the well-being of female and male factory workers [serial online] 2000 [diakses 12 April 2011]. Tersedia dari: URL: http://www.jstor.org

3. Badan Pusat Statistik. Keadaan ketenagakerjaan Indonesia Februari 2007. Jakarta; 2007.

4. Pedoman penanggulangan anemia gizi untuk remaja putri dan wanita usia subur [serial online] 2008 [diakses 12 April 2011]. Tersedia dari: URL: http://repository.usu.ac.id

5. Muhadjir D, Mahendra W. Kesehatan reproduksi pekerja wanita [serial online] 2004 [diakses $11 \mathrm{Mei}$ 2011]. Tersedia dari: URL: http://repository.ipb.ac.id

6. Novitasari D. Hubungan IMT dan kadar hemoglobin dengan produktivitas kerja pada tenaga kerja wanita [skripsi]. Semarang: Fakultas Kesehatan Masyarakat Universitas Diponegoro; 2005.

7. Astuti LT. Hubungan indeks massa tubuh, hemoglobin, dan kesegaran jasmani dengan produktivitas kerja pada tenaga kerja wanita bagian packaging (studi di PT Danliris, Banaran, Grogol, Sukoharjo) [skripsi]. Semarang: Fakultas Kesehatan Masyarakat Universitas Diponegoro; 2007.

8. Tarwaka, Solichul HB, Lilik S. Ergonomi untuk keselamatan kerja dan produktivitas. Surakarta: Uniba Press; 2004.hal. 8-11, 33, 67, 71-146

9. Nugroho VA. Hubungan antara status gizi dengan produktivitas tenaga kerja wanita di PT Java Tobacco Gembongan Kartasura [karya tulis ilmiah]. Semarang: Fakultas Ilmu Kesehatan Universitas Negeri Semarang; 2007.

10. Ariningsih E. Konsumsi dan kecukupan energi dan protein rumah tangga pedesaan di Indonesia: Analisis data susenas 1999, 2002, dan 2005. Jakarta: Pusat Analisis Sosial Ekonomi dan Kebijakan Pertanian; 2005.

11. Wolgemuth JC, Latham MC, Cesher A. Worker productivity and the nutritional status of Kenyan road construction laborers [serial online] 2002 [diakses 12 April 2011]. Tersedia dari: URL: http://www.ajcn.org

12. Martaniah SM, et al. Laporan penelitian hubungan antara tingkat terpenuhinya kebutuhan fisik minimal dan produktivitas kerja di Provinsi Jawa Tengah dan Sumatra Barat. Yogyakarta: Fakultas Psikologi Universitas Gadjah Mada; 2005.

13. Satyanaranaya K, Nadamuni N, Bina C, Narasinga R. Body size and work output [serial online] 2007 [diakses 17 Mei 2011]. Tersedia dari: URL: http://www.ajcn.org

14. Almatsier S. Prinsip dasar ilmu gizi. Jakarta: PT Gramedia Pustaka Utama; 2003.hal. 298-90.

15. Aji GK. Hubungan status anemia dan status gizi dengan produktivitas tenaga kerja perusahaan Refi Chemical Industry Daerah Istimewa Yogyakarta [karya tulis ilmiah]. Yogyakarta: Program Studi Kesehatan Fakultas Kedokteran: Universitas Gadjah Mada; 2007.

16. Garrow, John. Body Size and Composition In: Geissler C, Powers H. Human Nutrition, $11^{\text {th }}$ Edition. London: Elsevier Limited; 2005.p. 75-9.

17. Scholz BD, Rainer G, Werner S, Soemilah S. Anemia is associated with reduced productivity of women workers even in less-physically-strenuous tasks [serial online] 2006 [diakses 15 Mei 2011]. Tersedia dari: URL: http://www.bjn.org

18. Badan Perencanaan Pembangunan Nasional. Rencana aksi nasional pangan dan gizi 2006-2010. Jakarta; 2007.

19. Departemen Kesehatan Republik Indonesia. Petunjuk teknis gerakan pekerja wanita sehat dan produktif (GPWSP) bagi petugas perusahaan. Jakarta; 2002.

20. Untoro J, Gross R, Schultink W. The association between BMI and haemoglobin and work productivity among Indonesian female factory workers. European Journal of Clinical Nutrition. 2008. Feb; 52 (2): 131-5.

21. Oppusunggu R. Pengaruh pemberian tablet tambah darah $(\mathrm{Fe})$ terhadap produktivitas tenaga kerja wanita pensortir daun tembakau di PT X Kabupaten Deli Serdang [tesis]. Medan: Universitas Sumatera Utara; 2009.

22. Susanto H. Dinamika penanggulangan kemiskinan: tinjauan historis era orde baru. Jakarta: Khanata; 2006.

23. Notoatdmojo S. Pendidikan dan perilaku kesehatan. Jakarta: Rineka Cipta. 2003.hal:121-2.

24. Widajanti L. Survei konsumsi gizi. Semarang: Universitas Diponegoro; 2007.hal.41-5.

25. Sumapradja, Gutawa M, Fayakun YL, Widyastuti D. Proses asuhan gizi terstandar. Bandung: Persatuan Ahli Gizi Indonesia (PERSAGI) dan Asosiasi Dietisien Indonesia (AsDI); 2009.hal. 89. 
26. Jebb S, McCarthy D, Fry T. New body fat reference curves for adult. Obesity reviews (NAASO) [serial online] 2004 [diakses 17 Mei 2011];A156 (suppl):1032-1036. Tersedia dari: URL: http://www.tanita.co.uk

27. Mahan LK, Escott-Stumps S. Krause's food, nutrition \& diet therapy. $11^{\text {th }}$ edition. Philadelphia: Saunders; 2004.p. 285-90.

28. Dahlan S. Statistik untuk kedokteran dan kesehatan. Jakarta: Salemba Medika; 2008.hal. 158-95.

29. Supariasa IDN, Bakri B, Fajar I. Penilaian status gizi. Jakarta: EGC; 2002.hal. 48-9, 59, 88, 114, 312.

30. Harrington JM, Gill FS. Buku saku kesehatan kerja. Jakarta: EGC; 2005.

31. Budiono $S$. Bunga rampai hiperkes dan keselamatan kerja. Semarang: Badan Penerbit UNDIP; 2003.hal. 59, 147, 154, 265.

32. Kanashiro, Bartolini HM, Fukumoto RM, Uribe MN, Robert TG, Rebecca C, Bentley, Margaret. Formative research to develop a nutrition education intervention to improve dietary iron intake among women and adolescent girls through Community Kitchens in Lima, Peru. American Journal of Nutrition. 2003; 133; page: 3978S3991S.

33. Notoatmodjo S. Ilmu kesehatan masyarakat (prinsip-prinsip dasar). Jakarta: PT Rineka Cipta; 2003.hal. 118-20.

34. Nurul A, Roy K, Ahmed S, Tahmed, Shamsir AM. Nutritional status, dietary intake, and relevant knowledge of adult in Rural Bangladesh. Journal Health Population Nutrition. 2010.Vol.28;no.1;page:86-93.

35. Vriendt DT, Cristophe M, Wim V, Ilse P, and Stefaan DH. Determinants of nutrition knowledge in young and middle-aged Belgian women and the association with their dietary behavior. Appetite Journal. 2009. Vol.52; p:788-792.

36. Nursanyoto H. Ilmu gizi: Zat gizi utama. Jakarta: PT Golden Terayon Press; 1992.hal. 77-8.

37. Susilo S. Hubungan kadar hemoglobin dan intake kalori dengan produktivitas kerja tenaga kerja wanita pada bagian jahit kerah di PT Rodeo Semarang: Fakultas Kesehatan Masyarakat Universitas Diponegoro; 2000.

38. Syafiq A. Gizi dan kesehatan masyarakat. Jakarta: PT Raja Grafindo Persada; 2007.hal. 62-72, 176.

39. Karen S. Dietary intake, physical activity and risk for chronic diseasesof lifestyle among employees at a south african open-cast diamond mine [tesis]. Master of Nutrition Stellenbosch University; 2006.

40. Murray RK, Granner DK, Mayes PA, and Rodwell VW. Biokimia harper. Edisi 25. Jakarta: EGC; 2003.p. 61-5.

41. Depkes RI. Pedoman pengukuran kesegaran jasmani. Jakarta: Depkes RI Dirjen Pembinaan
Kesehatan Masyarakat Direktorat Bina Upaya Kesehatan Puskesmas; 2001.

42. Larry AT, Marshall JK. Dietary fat and body fat: a multivariate study of 205 adult females [serial online] 2002 [diakses 10 Mei 2011]. Available from: URL: http://www.ajcn.org

43. Guyton A, John EH. Buku ajar fisiologi kedokteran. Edisi 9. Jakarta: EGC; 1997.hal. 529-35, 648, 106374.

44. Price S, Wilson L. Patofisiologi: konsep klinis proses-proses penyakit. Edisi 4. Jakarta: EGC; 1995.hal. 232.

45. Sylvia AP, Lorraine MW. Sel darah merah: Dalam Patofisiologi konsep klinis proses-proses penyakit. Jakarta: EGC; 2001.hal. 231-2. 